\title{
Baudrillardian Concepts of Hyperreality and Simulacra in Margaret Atwood's Oryx and Crake
}

\author{
Behzad Pourgharib \\ Golestan University, Golestan, Iran \\ Afsaneh Pourebrahim \\ English Department, Faculty of Literature and Foreign Languages, Islamic
} Azad University, Iran

\section{Introduction}

it is dedicated to a Baudrillardian study of Margaret Atwood's Oryx and Crake. The examples of simulacra and hyperreality in the novel are mentioned and discussed. In addition, Baudrillard theory is used for explaining the events. The way the real is replaced by signs and the way hyperreal is created and influenced in the novel is also explained. Finally, a conclusion of the chapter is presented.

Margaret Atwood's Oryx and Crake is a post-apocalyptic novel and has many similarities with The Road. The protagonist of the story is Snowman who used to be called Jimmy before the catastrophe. Snowman lives near some creatures that are called Crakers. They were created by Jimmy's Friend, Crake. The progresses in science results in the catastrophe as Carke creates a disease that kills everybody expect him, Jimmy and Oryx. Crake kills Oryx and Jimmy kills Crake and thus he is left alone. At the end he sees several humans and contemplates killing them, but it is not revealed whether he kills them or not (Brooks, 2010).

Baudrillard's hyperreality and simulacra are elaborated in his book Simulacra and Simulation. Raking up the term hyperreality from a movement in modem art, Baudrillard identified the dissolution of relations between subject and object, real and fake, true and false, in the triumph of consumer capitalism. Simulation models produce simulacra, representations of the real, that are so omnipresent that it is henceforth impossible to distinguish the real from simulacra. He believes that today abstraction is no longer that of the map, the double, the mirror, or the concept. In discussing simulacra and hyperreality, Baudrillard points out Borges fable and suggests that simulation is no longer that of a territory, a referential being, or a substance. It is the generation by models of a real without origin or reality: a hyperreal. The territory does not precede the map anymore, nor does it survive it. It is nevertheless the map that precedes the territory - precession of simulacra - that 
engenders the territory, and if one must return to the fable, today it is the territory whose shreds slowly decline across the extent of the map. It is the real, and not the map, whose traces persist here and there in the deserts that are no longer those of the Empire, but ours. The desert of the real is itself.

Baudrillard considers Disneyland as a perfect model of all the entangled orders of simulacra. He points out that it is first of all a play of illusions and phantasms: the Pirates, the Frontier, the Future World, etc. This imaginary world is supposed to guarantee the success of the operation. But in fact, what attracts the crowds the most is the social microcosm, the religious, miniaturized pleasure of real America, of its constraints and joys. One parks outside and stands in line inside; one is altogether abandoned at the exit. The only phantasmagoria in this imaginary world lies in the gentleness and warmth of the crowd, and in the enough and excessive number of gadgets necessary to generate the multitudinous effect. The contrast with the absolute solitude of the parking lot - a veritable concentration camp - is total. Or, rather: inside, a whole panoply of gadgets magnetizes the crowd in directed flows - outside, solitude is directed at a single gadget: the automobile (Best, 1997).

\section{Hyperreality in Oryx and Crake}

The title of the novel is consisted of two names "Oryx and "Crake" which indicates that the two individuals are significant characters in the novel; of course, they are probably are in an order that are significant for Snowman, the protagonist of the novel. He was in love with Oryx and thus she was probably the most significant person for him. Also, Crake was Snowman's friend and he resulted in the extinction of humans. This is a post-apocalyptic novel with postmodern themes. Bartosch points out that this novel has postmodern themes and says that: "the postnatural environment is closely linked to postmodernism in that it links questions of nature and authenticity with social adjustments to simulacra and artificial environments. Jimmy/snowman's father is an example of such postnatural/postmodern adjustments" (Bartosch, 2013:p.227).

DVDs and CDs are like the map in Borges fable. These words (DVD and CD) are mentioned many times in the novel and thus they show that the era before the catastrophe has been a modern era with hyperreality. DVDs and CDs store signs of the real; they give hyperreality.

Advancement of science that leads to creation of hyperreality pointed out: 
Jimmy's father worked for OrganInc Farms. He was a genographer $[\ldots]$ he'd been one of the foremost architects of the pigoon project [...]. The goal of the pigoon project was to grow an assortment of foolproof human-tissue organs in a transgenic knockout pig host organs that would transplant smoothly and avoid rejection but would also be able to fend off attacks by opportunistic microbes and viruses, of which there were more strains every year (Atwood, 2010:p.18).

We see that there is hyperreality in the creation of something that is originated from human fantasies. Pigoons are not pigs but they are created and later we see that they exist after the catastrophe. Gnanamony is a scholar who also points out the scientific processes in the novel and says: "Atwood discusses quite a good number of scientific sensations of postmodern times in her Oryx and Crake. Digital technology is very much used in the modern microbiology and organ harvesting and transplantation fields" (Gwinner, 2011:p.228).

DVD is mentioned and it contains mostly hyperreality and the contents replace reality: "Jimmy watched Ramona eat. She took very small bites and managed to chew up the lettuce without crunching. The raw carrots too. That was amazing, as if she could liquefy those hard, crisp foods and suck them into herself, like an alien mosquito creature on DVD" (Atwood, 2010, 20). The alien mosquito creatures are hyperreal, and people get inspiration from them. The real is replaced with hyperreal.

Pigoons are significant human made creations that are related to the concept of hyperreality as they are originated from human fantasies and they may replace real pigs: 'The pigoons were much bigger and fatter than ordinary pigs, to leave room for all of the extra organs. They were kept in special buildings, heavily secured: the kidnapping of a pigoon and its finely honed genetic material by a rival outfit would have been a disaster' (Howells, 2006:p.21).

Hyperreality through TV is pointed out in the novel:

Jimmy had never been to the city. He'd only seen it on TV endless billboards and neon signs and stretches of buildings, tall and short; endless dingy-looking streets, countless vehicles of all kinds, some of them with clouds of smoke coming out the back; thousands of people, hurrying, cheering, rioting (Atwood, 2010:p.22-23). 
These are all memories of Snowman. This is like the example given by Leitch et al in which they gave the example of a student who is starting college and he or she has so many images of college students (from movies or TV) in mind that his or her way of being a student will inevitably be patterned in response to those preexisting concepts and images. We see here that the image and signs prevail, and Jimmy does not see the real city but digital contents that prevent authentic experience.

Compound people in the novel almost imprison themselves: 'Compound people didn't go to the cities unless they had to, and then never alone. They called the cities the pleeblands' (Atwood, 2010:p.23). They work in order to create a better world, but they imprison themselves and the result is not really a better world.

It is somehow suggested that Snowman is not Jimmy anymore: 'Snowman has a clear image of his mother - of Jimmy's mother - sitting at the kitchen table, still in her bathrobe when he came home from school for his lunch' (Crane,2012:p.26). He begins to forget what his father looked like and her father is reduced to some images in his memory and in fact some simulacra:

What did his father look like? Snowman can't get a fix on it. Jimmy's mother persists as a clear image, full color, with a glossy white paper frame around her like a Polaroid, but he can recall his father only in details: the Adam's apple going up and down when he swallowed, the ears backlit against the kitchen window, the left hand lying on the table, cut off by the shirt cuff. His father is a sort of pastiche. Maybe Jimmy could never get far enough away from him to see all the parts at once (Atwood, 2010:p.39).

The real does not exist anymore and some memories of his father exist. He even forgets the memories of his tenth birthday: 'So Snowman has forgotten everything else about Jimmy's tenth birthday except the rakunk, brought home by his father in a carry-cage' (Atwood, 2010:p.40). Thus, the real is lost and only some memories of it are remained.

His parents had created a situation in which they became like prisoners:

Jimmy's mother said that didn't change the fact that she felt like a prisoner. Jimmy's father said she didn't understand the reality of the situation. Didn't she want to be safe, didn't she want her son to be safe? "So it's for my own good?" she said. She was cutting a piece of French toast into even-sided cubes, taking her time. "For our own good. For us." (Atwood, 2010:p.43). 
They lived in a world of hyperreality because they abandoned the real life and they chose a lifestyle that imprisoned them. So, the concept of the better life they have created for themselves is more real than the real living for them.

As it was pointed out before, Crake is one of the significant characters in the novel and his appearance is mentioned as follow:

A few months before Jimmy's mother vanished, Crake appeared. The two things happened in the same year. What was the connection? There wasn't one, except that the two of them seemed to get on well together. Crake was among the scant handful of Jimmy's friends that his mother liked. Mostly she'd found his male pals juvenile, his female ones airheaded or sluttish. She'd never used those words, but you could tell (Atwood, 2010:p.59).

The concept of virtual reality is also a significant concept related to hyperreality that is explained by Baudrillard and manifested in the novel. Games on the web are examples of virtual reality that are mentioned in the novel: 'By unspoken consent they'd given up on Blood and Roses, which was fine with Crake because he was into something new - Extinctathon, an interactive biofreak masterlore game he'd found on the Web' (Thomas,2007:p.70). In chapter two it was pointed out that Best and Kellner mentioned that that simulation for Baudrillard describes a process of replacing "real" with "virtual" or simulated events, as when electronic or digitized images, signs or spectacles substitute "real life" and objects in the real world. Here in the novel we see that Snowman remembers those times when he and Carke played games on the web. These games are examples of simulation and the real is replaced with something else. The games are hyperreal. Also, websites represent simulation as they try to replace the real world and give the feeling of being real: "Shortcircuit.com, brainfrizz.com, and deathrowlive.com were the best; they showed electrocutions and lethal injections. Once they'd made real-time coverage legal, the guys being executed had started hamming it up for the cameras" (Gallardo, 2014:p.72). Gallardo and Russell point out these games and say: "Crake and Jimmy play computer games almost all the time, not only just exploring cyberspace, but primarily delving into the illusion of freedom it offers" (Atwood, 2010:p.329).

He liked Oryx and he first knew her from a porn video:

Oryx paused in her activities. She smiled a hard little smile that made her appear much older, and wiped the whipped cream from her mouth. Then she looked over her shoulder and right into the eyes of the viewer - right into Jimmy's eyes, into the secret person 
inside him. I see you, that look said. I see you watching. I know you. I know what you want [...]. This a keeper?" Crake said. "You want it?" "Yeah," said Jimmy. He could barely get the word out. He hoped he sounded normal. So, Crake had printed it, the picture of Oryx looking, and Snowman had saved it and saved it. He'd shown it to Oryx many years later (Atwood, 2010:p.81).

Thus, Jimmy was in love with the hyperreal girl in the video. The hyperreality resulted in a seduction. This is one of the significant examples of the impact of technology through hyperreality and it was one of the topics of discussion by Baudrillard. Germana and Mousoutzanis point out the virtual reality and say "It is quite telling that Crake's first encounter with Oryx takes place via a website providing virtual sex experience: consumed through a screen, her virtual body is the mediated reproduction of the eroticized body; her virtual prostitution caters to the projected fantasies and fabricated narratives of the globalized hyperreal world of Oryx and Crake (Gane, 2000:p.210).

The advancement of biotechnology has resulted in creation of different creatures. The concepts that have been created by movies and imaginations have come to reality by humans. Humans have destroyed the reality and created a hyperreal world. They have eliminated the real and substitute it with the fake and copy.

Some information about Oryx is revealed:

When Jimmy was seven or eight or nine, Oryx was born. Where, exactly? Hard to tell. Some distant, foreign place. It was a village though, said Oryx. A village with trees all around and fields nearby, or possibly rice paddies. The huts had thatch of some kind on the roofs - palm fronds? - although the best huts had roofs of tin. A village in Indonesia, or else Myanmar? Not those, said Oryx, though she couldn't be sure. It wasn't India though. Vietnam? Jimmy guessed. Cambodia? Oryx looked down at her hands, examining her nails. It didn't matter [...]. This village was a place where everyone was poor and there were many children, said Oryx. She herself was quite little when she was sold. Her mother had a number of children, among them two older sons who would soon be able to work in the fields, which was a good thing because the father was sick. He coughed and coughed; this coughing punctuated her earliest memories (Atwood, 2010:p.101). 
Thus, it is revealed that there was a high level of inequality in the world and a girl like Oryx was sold by his family due to poverty. Oryx tells her story of the way she became a sex worker:

He unlocked a door with a key, and they went in, and he locked the door behind them, and they were in a mauve-and-gold-coloured room with a giant bed in it, a bed for giants, and the man asked Oryx to take off her dress. Oryx was obedient and did as she was told. She had a general idea of what else the man might want - the other children already knew about such things and discussed them freely, and laughed about them (Atwood, 2010:p.117).

She is forced into playing in porn movies which are an example of hyperreality: "The building where the movies were made was in a different city, or it might have been in a different part of the same city, because the city was very big, said Oryx. The room she stayed in with the other girls was in that building too" (Atwood, 2010:p.124). As it was pointed out in chapter two, porno videos stimulate libido in abstraction from the problems of real relations with others and reduce complex gender identities to mere sex puppets. Here too, Jimmy is more attracted to Oryx in a sexual way and this is mostly because he fell in love withering her after seeing her in a porn movie.

Crake had tried to engineer men and thus make them different and hyperreal:

Crake had worked for years on the purring. Once he'd discovered that the cat family purred at the same frequency as the ultrasound used on bone fractures and skin lesions and were thus equipped with their own self-healing mechanism, he'd turned himself inside out in the attempt to install that feature. The trick was to get the hyoid apparatus modified and the voluntary nerve pathways connected, and the neocortex control systems adapted without hampering the speech abilities. There'd been quite a few botched experiments, as Snowman recalled (Atwood, 2010:p.140).

Humans try to invent new things and these things gradually replace the real world. They are hyperreal that become real after the real itself has eliminated. Hester suggests that 'In the hyperreal dystopia of Oryx and Crake, however, reality fails to live up to the standards of simulation' (Atwood, 2010:p.98). The results of Crake's experiments are Crakers that try to simulate humans and thus they become the reality after humans have become extinct. The hyperreal becomes real in the case of Pigoons and Crakers. 
Snowman recalls that there was a protest against genetically-modified coffee beans called: Happicuppa: 'but there was Happicuppa coverage, it seemed, wherever you turned. There were protests and demonstrations, with tear gas and shooting and bludgeoning; then more protests, more demonstrations, more tear gas, more shooting, more bludgeoning' (Atwood, 2010:p.160). The real is lost and replaced by something else but they sell it as real. They sell the hyperreal as if it is real. They sell genetically modified coffee as normal coffee or a safe and healthy coffee.

As Baudrillard pointed out the world is reduced to words through knowledge and thus the signs take the place of the things signified. Libraries are examples of this, and they are pointed out in the novel: "Better libraries, at institutions with more money, had long ago burned their actual books and kept everything on CD-ROM, but Martha Graham was behind the times in that, as in everything" (Poster, 2001:p.175). In the above quotation we see that CD-ROM has emerged as a new tool and has replaced paper books. CD is also an equivalent of the map in Borges fable as it contains the knowledge of the world through storing books.

Crake works in a place in which people are going too far:

They aren't dogs, they just look like dogs. They're wolvogs they're bred to deceive. Reach out to pat them, they'll take your hand off. There's a large pit-bull component." "Why make a dog like that?" said Jimmy, taking a step back. "Who'd want one?" "It's a CorpSeCorps thing," said Crake. "Commission work. A lot of funding. They want to put them in moats, or something." "Moats?" "Yeah. Better than an alarm system - no way of disarming these guys. And no way of making pals with them, not like real dogs." "What if they get out? Go on the rampage? Start breeding, then the population spirals out of control - like those big green rabbits?" "That would be a problem," said Crake. "But they won't get out. Nature is to zoos as God is to churches." "Meaning what?" said Jimmy. He wasn't paying close attention, he was worrying about the ChickieNobs and the wolvogs. Why is it he feels some line has been crossed, some boundary transgressed? How much is too much, how far is too far? (Atwood, 2010:pp.186187).

They want to change the real with something fake that is copied from the nature and modified. One of the differences between Crake and Jimmy is that Crake has a mentality which is focused on productiveness, but Jimmy pays more attention to his human needs including sexual needs: 
"Pair-bonding at this stage is not encouraged," said Crake, sounding like a guidebook. "We're supposed to be focusing on our work." "Bad for your health," said Jimmy. "You should get yourself fixed up." "Easy for you to say," said Crake. "You're the grasshopper, I'm the ant. I can't waste time in unproductive random scanning." (Atwood, 2010:p.188).

Crake says that HelthWyzer creates new diseases so that people need doctors and their services:

"So, you'd need more sick people. Or else - and it might be the same thing - more diseases. New and different ones. Right?" "Stands to reason," said Jimmy after a moment. It did, too. "But don't they keep discovering new diseases?" "Not discovering," said Crake. "They're creating them." "Who is?" said Jimmy. Saboteurs, terrorists, is that what Crake meant? It was well known they went in for that kind of thing or tried to. So far, they hadn't had a lot of successes: their puny little diseases had been simpleminded, in Compound terms, and fairly easy to contain. "HelthWyzer," said Crake. "They've been doing it for years. There's a whole secret unit working on nothing else. Then there's the distribution end. Listen, this is brilliant. They put the hostile bioforms into their vitamin pills - their HelthWyzer over-thecounter premium brand, you know? [....]Naturally they develop the antidotes at the same time as they're customizing the bugs, but they hold those in reserve, they practice the economics of scarcity, so they're guaranteed high profits." (Atwood, 2010:pp.191-192).

Thus, the research center focuses on how to generate more money rather than how to act in the direction of human benefit. It is the consumer society in which the fake needs replace real needs. The hyperreal replaces the real. They see the need for more disease, and they create more disease to generate more money. And "The best diseases, from a business point of view," said Crake, "would be those that cause lingering illnesses. Ideally - that is, for maximum profit - the patient should either get well or die just before all of his or her money runs out. It's a fine calculation." (Atwood, 2010:p.192).

Snowman sees a house and enters the house: "Next door there's a child's room, with a computer in gay red plastic, shelf of teddy bears, a wallpaper frieze of giraffes, and a stash of CDs containing - judging from the pictures on them - some 
extremely violent computer games. But there's no child, no child's body" The computer games are hyperreal. He hears a human voice in radio:

Suddenly there's an answer. It's a voice, a human voice. Unfortunately, it's speaking some language that sounds like Russian. Snowman can't believe his ears. He's not the only one then - someone else has made it through, someone of his own species. Someone who knows how to work a short-wave transmitter. And if one, then likely others. But this one isn't much use to Snowman, he's too far away (Atwood, 2010:p.247).

Thus, it is gradually revealed that he is not the only survivor. It is revealed gradually that the catastrophe was related to Crake: "There were signs, Snowman thinks. There were signs and I missed them. For instance, Crake said once, 'Would you kill someone you loved to spare them pain?' 'You mean, commit euthanasia?' said Jimmy (Atwood, 2010:p.292).

It is revealed that: "At first Jimmy thought it was routine, another minor epidemic or splotch of bioterrorism, just another news item [...]Then the next one hit, and the next, the next, the next, rapid-fire. Taiwan, Bangkok, Saudi Arabia, Bombay, Paris, Berlin. The pleeblands west of Chicago" (Atwood, 2010:p.296). It is revealed that Jimmy was immune and later Crake kills Oryx and Jimmy shots him.

There is mentioning of movies on DVD:

Finally, there was nothing more to watch, except old movies on DVD. He watched Humphrey Bogart and Edward G. Robinson in Key Largo. He wants more, don't you, Rocco? Yeah, that's it, more! That's right, I want more. Will you ever get enough? Or else he watched Alfred Hitchcock's The Birds. Flapflapflap, eek, screech. You could see the strings where the avian superstars were tied to the roof. Or he watched Night of the Living Dead. Lurch, aargh, gnaw, choke, gurgle. Such minor paranoias were soothing to him (Atwood, 2010:p.314).

The movies are hyperreality. They are digital images that fake the reality. He changed his name: "My name is Snowman," said Jimmy, who had thought this over. He no longer wanted to be Jimmy, or even Jim, and especially not Thickney" (Atwood, 2010:p.317). Thus, this indicates that the things signified can be called by anything and the signs that signify them are just arbitrary signs. 
The Crakers begin art: " 'We knew we could call you, and you would hear us and come back.' Not Amen, then. Snowman. 'We made a picture of you, to help us send out our voices to you.' Watch out for art, Crake used to say. As soon as they start doing art, we're in trouble" (p.327). They progress like humans. The Crakers says that they saw some people: And then later he sees them, and he contemplates killing them but the book finishes without revealing the result: "Should he kill them in cold blood? Is he able to? And if he starts killing them and then stops, one of them will kill him first. Naturally. "What do you want me to do?" he whispers to the empty air [...] Zero hour, Snowman thinks. Time to go" (Atwood, 2010:pp.336-337). Thus, it is not revealed that whether he helps the Crake's action of eliminating the human race.

\section{Simulacra in Oryx and Crake}

The time is after a catastrophe has resulted in human extinction. An infection created by Crake resulted in human extinction. The setting is very similar to McCarthy's The Road though there are also some differences. At the beginning it seems that only Snowman has survived but at the end of the novel he sees several other humans. The story is mostly consisted of memories of Snowman and is presented in the form of flashbacks.

At the beginning the loss of knowledge of time is pointe out:

Out of habit he looks at his watch - stainless-steel case, burnished aluminum band, still shiny although it no longer works. He wears it now as his only talisman. A blank face is what it shows him: zero hour. It causes a jolt of terror to run through him, this absence of official time. Nobody nowhere knows what time it is (Atwood, 2010:p.3).

Thus, human made symbols that represented date and time are destroyed and here we see the elimination of simulacra with the elimination of human race. And some of the human made things and concepts have become simulacra themselves. Baudrillard suggested the obliteration of nature by culture, particularly the replacement of the real by signs. Thus, humans invented time and date which were signs to represent the real and now with destruction of humans in the novel those signs are eroded, and simulacra is eliminated with regard to time. Human inventions such as time and date which represent the changes in day and night and seasons and are signs that represent the real are eliminated, similar to what happened in McCarthy's The Road. One of the main differences of this novel with The Road is that there are still living insects and probably animals and trees in this novel: "He walks a couple of yards to the left, pisses into the bushes. "Heads up," 
he says to the grasshoppers that whir away at the impact" (Atwood, 2010:p.3). But in The Road even trees were dead as the catastrophe impacted everything in that novel. Crane points out simulacrum in the novel and asserts that:

The many manifestations of Oryx are combined within Jimmy's narrative of her, creating a trance -like identity, only loosely connected by virtue of her simulacrum - like image appearing in a number of contexts, all of which evolve a round exploitation. It is thus not only possible to read her as a feminized, exoticized other, but also as a nonidentity, excluded from subjectivity, reduced to a product, perhaps a product of the West (Atwood, 2010:p.172).

There are children of Crake in the novel, things that are not completely human and they are created by Crake:

On the white beach, ground-up coral and broken bones, a group of the children are walking. They must have been swimming; they're still wet and glistening. They should be more careful: who knows what may infest the lagoon? But they're unwary; unlike Snowman, who won't dip a toe in there even at night, when the sun can't get at him. Revision: especially at night (Atwood, 2010:p.5).

It can be said that real humans have been replaced by some creatures that are made by Crake and are supposed to be similar to humans. Thus, these are hyperreal creatures that have come into reality. These have been engineered to have specific features:

"I want feathers too," says the youngest. A vain hope: no beards on the men, among the Children of Crake. Crake himself had found beards irrational; also, he'd been irritated by the task of shaving, so he'd abolished the need for it. Though not of course for Snowman: too late for him. Now they all begin at once. "Oh Snowman, oh Snowman, can we have feathers too, please?" "No," he says. "Why not, why not?" sing the two smallest ones. "Just a minute, I'll ask Crake." He holds his watch up to the sky, turns it around on his wrist, and then puts it to his ear as if listening to it. They follow each motion, enthralled. "No," he says. "Crake says you can't. No feathers for you. Now piss off." (Atwood, 2010:pp.7-8).

The extinction of humans is pointed out multiple times in the novel. Now even the voice of another human has been turned into simulacra as it is only in the memory of Snowman and his memory is like the map in Borges fable that was pointed out 
by Baudrillard: "He feels the need to hear a human voice - a fully human voice, like his own. Sometimes he laughs like a hyena or roars like a lion - his idea of a hyena, his idea of a lion. He used to watch old DVDs of such creatures when he was a child [...]" (Atwood, 2010:p.9).

Even food is scarce in that condition in which Snowman lives, similar to The Road: "He used to take good care of himself; he used to run, work out at the gym. Now he can see his own ribs: he's wasting away. Not enough animal protein" (Atwood, 2010 , 9). Thus, most foods that were available before the catastrophe do not exist anymore and they are just simulacra in the memory of Snowman. In thinking about the past, it is revealed that Snowman's name was Jimmy: "Once the fight got going Jimmy felt relieved, because he'd known then that he wouldn't be punished. All he had to do was say nothing and pretty soon they'd forget why they'd started arguing in the first place" (Atwood, 2010, 12). This indicates that Jimmy no longer exists, and it exists just in the memory of Snowman. It is a simulacrum that only exists in his memory.

It seems that there was a disease which led people to burn the corpse of animals:

Why were the cows and sheep on fire?" Jimmy asked his father the next day. They were having breakfast, all three of them together, so it must have been a Sunday. That was the day when his mother and his father were both there at breakfast. Jimmy's father was on his second cup of coffee. While he drank it, he was making notes on a page covered with numbers. "They had to be burned," he said, "to keep it from spreading." He didn't look up; he was fooling with his pocket calculator, jotting with his pencil. "What from spreading?" "The disease." "What's a disease?" "A disease is like when you have a cough," said his mother. "If I have a cough, will I be burned up?" "Most likely," said his father, turning over the page (Atwood, 2010:p.15).

Most human inventions are destroyed, especially things that were related to signs and culture. Season and calendar are among these things and they do not exist anymore: "Crake turned up at HelthWyzer High in September or October, one of those months that used to be called autumn" (Lister, 2009:p.60). The names given to things and concepts by humans including seasons are forgotten and this is erosion of simulacra as the reality exists without names and signs given and attributed to them. But at the same time, those concepts became simulacra as they did not have referents after the catastrophe. Thus, in this novel, similar to The 
Road, some signs are no longer used for the things signified and the reality precedes the image and the sign, and they are no longer named.

The knowledge on CDs and DVDs are signs that want to represent the reality. The reality is reduced to signs and images. The following sentence from the novel clarifies this : "But Jimmy had found it in the Encyclopedia Britannica, 1957 edition, which was stored on CD-ROM - for some forgotten reason - in the school library" (Atwood, 2010:p.37). In the aforementioned sentence we see that the world and knowledge of the world are reduced to signs and those signs are stored on CDs. But when the humanity is eliminated most of this knowledge becomes simulacra as it refers to things that do not exist anymore. Virtual world on CDs and internet are pointed out several times in the novel. Belyea discusses virtuality in the novel and asserts that: "Indeed virtuality is among the main themes in Oryx and Crake, and Atwood criticizes Jimmy and Crake's obsession with the internet to have us consider the authenticity and the heavy investment we tent to make in it, whether in terms of words, language, gender, nation, race, or even, yes, species itself" (Atwood, 2010:p.190).

Children constantly ask Snowman questions and he is like a god to them who knows everything:

"Oh Snowman, tell us about when Crake was born," says one of the women. This is a new request. He isn't ready for it, though he should have expected it: children are of great interest to these women. Careful, he tells himself. Once he provides a mother and a birth scene and an infant Crake for them, they'll want the details. They'll want to know when Crake cut his first tooth and spoke his first word and ate his first root, and other such banalities. "Crake was never born," says Snowman. "He came down out of the sky, like thunder. Now go away please, I'm tired." He'll add to this fable later. Maybe he'll endow Crake with horns, and wings of fire, and allow him a tail for good measure (Atwood, 2010:p.92).

The Crakers are called the children of Crake: "After the Children of Crake have filed away, taking their torches with them, Snowman clambers up his tree and tries to sleep" (Atwood, 2010, 94). These creatures are similar to humans. The world after the catastrophe is filled with things copied from the nature but they have now replaced the reality and the originals. Another example of these creatures that are made by humans and come into reality is Wolvog:

"Hello, my furry pals," he calls down. "Who wants to be man's best friend?" In answer there's a supplicating whine. That's the 
worst thing about wolvogs: they still look like dogs, still behave like dogs, pricking up their ears, making playful puppy leaps and bounces, wagging their tails. They'll sucker you in, then go for you. It hasn't taken much to reverse fifty thousand years of mancanid interaction. As for the real dogs, they never stood a chance: the wolvogs have simply killed and eaten all those who'd shown signs of vestigial domesticated status. He's seen a wolvog advance to a yapping Pekinese in a friendly manner, sniff its bum, then lunge for its throat, shake it like a mop, and canter off with the limp body (Atwood, 2010:p.96).

There are still birds in the post-apocalyptic setting of the novel: "A long scrawl of birds unwinds from the empty towers - gulls, egrets, herons, heading off to fish along the shore" (Bernardo, 131). Thus, unlike the setting of The Road in which most of the living creatures had died, here there are many animals and it seems that the infection that has killed people has not impacted many types of animals.

Snowman needs food, some foods have become nonexistent and simulacra as only their names and the memory of their tastes are remained, and this is suggested several times in the novel; it is pointed out that:

Time to face reality. Crudely put, he's slowly starving to death. A fish a week is all he can depend on, and the people take that literally: it can be a decent-sized fish or a very small one, all spikes and bones. He knows that if he doesn't balance out the protein with starches and that other stuff - carbohydrates or are those the same as starches? - he'll start dissolving his own fat, what's left of it, and after that his own muscles. The heart is a muscle. He pictures his heart, shrivelling up until it's no bigger than a walnut (Atwood, 2010:p.133).

Pigoons which are the result of human activities are remained:

He could trap a pigoon, bludgeon it to death, butcher it in secret. He'd have to hide the mess: he has a notion that the sight of fully frontal blood and guts might take him over the threshold as far as the Children of Crake are concerned. But a pigoon feast would do him a world of good. Pigoons are fat, and fat is a carbohydrate. Or is it? He searches his mind for some lesson or long-lost chart that would tell him: he knew that stuff once, but it's no use, the file folders are empty (Atwood, 2010:p.134). 
Crake says once suppose that civilization is destroyed, and instructions remain (like the map in Borges fable):

"Actually not," said Crake. "It's not like the wheel, it's too complex now. Suppose the instructions survived, suppose there were any people left with the knowledge to read them. Those people would be few and far between, and they wouldn't have the tools. Remember, no electricity. Then once those people died, that would be it. They'd have no apprentices, they'd have no successors. Want a beer?" "Is it cold?" "All it takes," said Crake, "is the elimination of one generation. One generation of anything. Beetles, trees, microbes, scientists, speakers of French, whatever. Break the link in time between one generation and the next, and it's game over forever." (Atwood, 2010:p.102).

He points out simulacra here. He suggests that there can be some situation in which simulacra cannot be used to restore and rebuild the real thing. He suggests that some natural elements are necessary and without them no one can create anything from signs. This is very significant. It shows the uselessness of the signs in some conditions and that in some conditions the things are no longer represented by the signs used to signify them. Gallardo and Russell assert that in fact, for Crake and Jimmy, as we may assume the typical representatives of the future intelligentsia, "science and all its possibilities raging from cyberspace to high-tech gadgets constitutes a reality that is both dangerous and alluring. Consequently, the question of moral indifferences as an outcome of the process of science arises here" (Belyea, 2013:p.329).

Even Christmas does not exist anymore for him: "Instead he begins to hum, to cheer himself up. What's the song? "Winter Wonderland." They used to recycle that in the malls every Christmas, long after the last time it snowed. Some tune about playing pranks on a snowman, before it got mushed" (Atwood, 2010:p.203). Christmas is an annual festival. It is a part of culture and like other festivals it is a human creation. But after the catastrophe there is no date and calendar for determining Christmas and even if there was it would not be probably remembered by Snowman as he is in a situation that he tries not die and tries to survive and he cannot care about festivals. Thus, the term Christmas has become a simulacrum in the mind of Snowman. 


\section{Conclusion}

It provided a detailed analysis of Atwood's Oryx and Crake using Baudrillard theory. Multiple examples of simulacra and hyperreality were seen and analyzed in the novel. Technology played a significant role in the events in this novel. It was revealed that there were some similarities between Atwood's Oryx and Crake and McCarthy's The Road. Overall, this novel focused more on technology and hyperreality and simulacra created due to technology. Unlike McCarthy's The Road, this novel presented a full view of the cause of the catastrophe and the things that resulted to the catastrophe. In this novel, similar to The Road, it was found that some signs were no longer used for the things signified and the reality preceded the image and the sign, and they no longer had a name. It was seen in the novel that the world and knowledge of the world were turned into signs and those signs were stored on CDs. But when the humanity was wiped out most of this knowledge became simulacra. The concept of virtual reality was also a major notion that was discussed by Baudrillard and manifested in the novel. Games on the web were examples of virtual reality that were seen in the novel. It was found that games were some examples of simulation and the real was replaced with something else. The games were hyperreal. Also, websites were instances of simulation as they tried to replace the real world and present the feeling of being real in the novel. It was found out that Jimmy fell in love with the hyperreal girl in the video, Oryx. The hyperreality contributed to the seduction. This was one of the major examples of the effect of technology through hyperreality and it was one of the topics discussed by Baudrillard. It was seen that the progress in biotechnology had resulted in creation of multiple creatures in the society before the catastrophe. The notions that had been constructed by movies and imaginations came into reality by humans. Humans had eliminated the reality and constructed a hyperreal world. Oryx was forced into participating in porn videos which were examples of hyperreality.

\section{References}

Atwood, M. (2010). Oryx and Crake. Canada: Knopf Canada, PDF

Bartosch, R. (2013). EnvironMentality.: Ecocriticism and the Event of Postcolonial Fiction. New York: Rodopi.

Baudrillard, J. (1994). Simulacra and Simulation. Michigan: University of Michigan Press, PDF.

Belyea, A. (2013). "Is "Eco" Enough? Margaret Atwood's Oryx and Crake, Wayland Drew's The Erthring Cycle, and Evolutionary Fiction." Ed. Norris, N. Words for a Small Planet: Ecocritical Views. New York: Rowman \& Littlefield. 
Bernardo, S., Palumbo, D., and Sullivan, C. (2014). Environments in Science Fiction: Essays on Alternative Spaces. Jefferson: McFarland.

Best, S. and Kellner, D. (1997). The Postmodern Turn. New York and London: Guilford Press.

Brooks Bouson, J. (2010). Margaret Atwood: The Robber Bride, The Blind Assassin, Oryx and Crake. London and New York: Continuum.

Crane, C. (2012). Myths of Wilderness in Contemporary Narratives: Environmental Postcolonialism in Australia and Canada. New York: Palgrave Macmillan.

Gallardo, P. and Russell, E. (2014). Yesterday's Tomorrows: On Utopia and Dystopia. Newcastle: Cambridge Scholars Publishing.

Gane, M. (2000). Jean Baudrillard: In Radical Uncertainty. London: Pluto Press.

Gwinner, Donovan. (2011). ““Everything uncoupled from its shoring”: Quandaries of Epistemology and Ethics in The Road". Ed. Spurgeon, Sara. Cormac McCarthy: All the Pretty Horses, No Country for Old Men, The Road. London: A\&C Black.

Howells, C. A. (2006). The Cambridge Companion to Margaret Atwood. Cambridge: Cambridge University Press.

Lane, Richard. J. (2008). Jean Baudrillard. New York: Routledge.

Lister, M. (2009). New Media: A Critical Introduction. London and New York: Routledge.

Poster, M. (Ed). (2001). Jean Baudrillard: Selected Writings. Stanford: Stanford University Press.

Thomas, Paul. (2007). Lee. Reading, Learning, Teaching Margaret Atwood. New York: Peter Lang. 


\title{
Summary
}

\section{Baudrillardian Concepts of Hyperreality and Simulacra in Margaret Atwood's Oryx and Crake}

\author{
Behzad Pourgharib \\ Golestan University, Golestan, Iran
}

\author{
Afsaneh Pourebrahim \\ English Department, Faculty of Literature and Foreign Languages, Islamic \\ Azad University Karaj Branch, Iran
}

The study attempts to analyze Margaret Atwood Oryx and Crake in the light of Baudrillard Theory. The discussion is based on Baudrillard theory of Hyperreality and Simulacra. Margaret Atwood's novel Oryx and Crake (2003) takes place in a future time where there are scientific progresses. The protagonist of the story is Snowman who used to be called Jimmy and who is the son of two genetic scientists. Snowman lives near some creatures that are called Crakers. When jimmy is near starvation, he decides to search for food in the ruins of RejoovenEsence. Jimmy and Oryx develop a relationship. The human race is wiped out and Jimmy realizes that all of these are planned by Crake. Crake says that the three of them are immune to the virus. Crake kills Oryx and he is killed by Jimmy. Jimmy also gets a disease and finally finds three humans, two men and a woman, and he does not know whether to kill them or become friend with them. He makes up his mind and goes towards them and the story ends there. It can be said that there is elimination of hyperreality in the novel as there is the decline of civilization. Baudrillard's hyperreality explained the situation in the consumer society in which the real was lost. Thus, it can be said that the catastrophe in the novel has resulted in the elimination of the civilization, consumer society and thus hyperreality in the consumer society. But it should be pointed out that there is also hyperreality created due to the catastrophe because things are no longer what they used to be and some human made structures have lost their function, similar to the map in the Borges fable pointed out by Baudrillard.

Keywords: Baudrillard, hyperreality, simulacra, Margaret Atwood, Oryx and Crake 